\title{
TATIAN'S CHRISTOLOGY AND ITS INFLUENCE ON THE COMPOSITION OF THE DIATESSARON
}

\author{
Peter M. Head \\ Introduction
}

'Tatian did not only re-arrange the evangelical tradition into a harmony, but when composing the Diatessaron left his fingerprints on its pages'.1 Vööbus' statement concerning Tatian's Diatessaron has been reformulated recently in Petersen's survey of research: 'like any document created in a particular time and place, the Diatessaron reflects the theology and praxis of its locale' ${ }^{2}$ The aim of this article is to investigate whether christological factors played any significant role in Tatian's composition. This issue is important for two reasons. Firstly, the Diatessaron is the earliest and most influential of gospel harmonies (the standard tool for gospel studies throughout the patristic and reformation periods). 3 Secondly, as a redaction of the canonical gospels,

${ }^{1}$ A. Vööbus, Early Versions of the New Testament (PETSE 6; Stockholm, 1954) 22.

2W.L. Petersen, 'Tatian's Diatessaron' in H. Koester, Ancient Christian Gospels: Their History and Development (London, 1990) 403.

${ }^{3}$ The Harmony of Ammonius (referred to by Eusebius in his letter to Carpianus) is nowhere extant; according to Eusebius' description it would be more like a synopsis based around the text of Matthew than a harmony; see H.H. Oliver, "The Epistle of Eusebius to Carpianus. Textual Tradition and Translation' NovT 3 (1959) 138-145. Another Harmony by Theophilus is mentioned by Jerome (Ep. 121.6). Tatian's Diatessaron embodies a harmonistic tendency that was widespread in the early period (e.g., the Gospel of Peter, the Gospel of the Ebionites, the Secret Gospel of Mark; also a common feature of scribal alterations to gospel manuscripts and of the commentaries of Origen and Augustine). This harmonistic tendency was also characteristic of Justin Martyr (Tatian's teacher), see A.J. Bellinzoni, The Sayings of Jesus in the Writings of Justin Martyr (NovTSS 17; Leiden, 1967) 140-142; and W.L. Petersen, 'Textual Evidence of Tatian's Dependence upon Justin's AПOMNHMONEYMATA' NTS 36 (1990) 512-534. 
the Diatessaron mirrors other second century gospel-redactors (and may illustrate first-century practices). 4

For the most part, scholars have focussed on the influence of Tatian's Encratite tendencies, especially important since it was his stance against marriage (among other things) which caused Tatian to be regarded as a heretic by many Western Church Fathers. ${ }^{5}$ Another influence that has been suggested by various scholars is an anti-Jewish tendency. ${ }^{6}$ It is notable that the influence of Tatian's Christology has not been discussed. The influence of an individual's Christology on his understanding and re-presentation of the gospel stories is considerable (even for modern Christians). Tatian, who exercised such care in the composition of his four-fold gospel, is therefore of considerable interest in this regard.

The present article will discuss: (I) the life and Christology of Tatian, showing that the question of the christological orientation of the Diatessaron was considered very important in the late Patristic era; (II) the evidence for the Diatessaron, bearing in mind the question of it's attestation and which sources can be used in assessing Tatian's contribution; (III) the structure and content of the Diatessaron in relation to it's Christology - the bulk of the article discusses both structural and redaction-critical matters relating to the composition of the Diatessaron. Our overall concern is to determine the ways in which Tatian's arrangement, selection,

\footnotetext{
4Tatian appears to have had some access to non-canonical traditions, but these are clearly subordinate to the canonical Gospels in terms of amount of material and their importance, see J.H. Charlesworth, 'Tatian's Dependence Upon Apocryphal Traditions' HeyJ 15(1974)5-17. For 'christological redaction' in The Gospel of Peter see P.M. Head, 'On the Christology of the Gospel of Peter' VigChr (forthcoming, 1992).

5 Clement, Strom. 3.12; Origen, De Orat. 24; Jerome, Amos. 2:12; Titus preface; Gal. 6:8 (all these collected in M. Whittaker, Tatian: Oratio ad Graecos and fragments (Oxford, 1982) 78-83). The evidence from the Diatessaron will be discussed later.

6Suggested by A. Harnack, 'Tatians Diatessaron und Marcions Commentar zum Evangelium bei Ephraem Syrus' ZKG 4 (1880) 492ff; J.R. Harris, 'Was the Diatessaron Anti-Judaic?' HTR 18 (1925) 103-109. The evidence consists primarily in the more explicit identification of 'the Jews' as the agents throughout the passion narrative (so Dia. (Arabic) 49.52; 50.29; 50.50f; 51.15), and occasional universalistic emphases (Dia. 2.18).
} 
and modification of the canonical Gospels served to highlight his Christology.

\section{Tatian's Life, Work, and Christology7}

Tatian was born in Assyria of pagan parents (Oratio 42), and received a rhetorical education, acquiring a reputation for learnedness (Eus, HE. IV.16.7; cf., Oratio 35 \& 42). He travelled widely, and in Rome became a student of Justin Martyr, and a member of the church (Oratio 18, 29; Irenaeus, Adv. Haer. I.28.1; Eus, HE. IV.29.1). He in turn taught Clement of Alexandria ${ }^{8}$ and Rhodo (an opponent of Marcion; Eus, $H E$. V.13.1, 8). In addition he is mentioned in a treatise preserved by Eusebius (HE. V.28.4) as an apologist for the deity of Christ, along with Justin and Clement and others. Eusebius also refers to the vast quantity of his writings (HE. IV.29.7), 9 noting also that he 'ventured to paraphrase some words of the apostle [Paul], as though correcting their style' (HE. IV.29.6).

Tatian later broke away from the Roman church ${ }^{10}$ and returned to Mesopotamia, where he exerted considerable influence around Syria and Antioch. Irenaeus, Epiphanius, Eusebius, and Jerome all regarded him as the founder of the Encratites, 11 a rigourously ascetic sect which rejected the use of wine, meat and marriage. His writings exercised a strong influence over the Syrian church up until the fourth century and fifth centuries. 12

${ }^{7}$ For biographical information see (in addition to general works) J.M. Fuller, 'Tatianus' DCB IV (1887) 783-804; E. Preuschen, 'Untersuchungen zum Diatessaron Tatians' S.H.A.W. (Ph-h. Kl) IX:15 (1918) 8-30; Whittaker, Tatian, ix-xvii.

${ }^{8}$ This is the widely accepted interpretation of Strom. 1.1 and 11.2, where Clement refers to 'an Assyrian' among his teachers.

${ }^{9}$ Some of these are referred to in Oratio 14-16 (others in Clement, Strom. III.81.1f; Eus, HE. V.13.8).

${ }^{10}$ The date of the break is probably AD 172 (so Eus, Chron XII), see Whittaker, Tatian, ix; ODCC, 1341. Irenaeus suggested that he only went astray after Justin's death (Adv. Haer. I.28.1).

${ }^{11}$ Irenaeus, Adv. Haer. III.23.8 (\& Eus, HE. IV.29); Epiphanius, Panarion I.3.46; Eus, HE. IV.29.1; Jerome, Adv Iovinian 1, 3t II; 2.16 (Whittaker, Tatian, $x$ ); see also note 5 above.

${ }^{12}$ His influence was not, however, limited to the Syrian church: Clement refers to Tatian's 'accurate' account (Strom. 1.21); Eusebius commends the Oratio (HE. IV.29). 
It was not only his ethical teaching, however, that was regarded with suspicion. According to Jerome, Tatian had maintained that Christ's flesh was imaginary. ${ }^{13}$ Theodoret, Bishop of Cyrus, (AD 453) said that in the composition of the Diatessaron Tatian cut out the genealogies and such other passages as show the Lord to have been born of the seed of David after the flesh.'14 Victor, who was hesitant towards the Diatessaron because of Tatian's reputation, said:

even if Tatian wrote this book when he was already the leader of a heretical sect, I would readily accept the words of my Lord, which I know (to be true) and would reject whatever interpretation he added of his own.15

Ishodad of Merv (bishop of Hedhatta ca AD 850) in his description of the Diatessaron said: 'Tatianos. . .selected from the four gospels and combined and composed a Gospel and called it Diatessaron. . and on the Divinity of Christ he did not write.' 16

All of these writers suggest that Tatian's Diatessaron reflected his Christology, and that by omission (Theodoret and Ishodad) and addition (Jerome and Victor) he had placed his own interpretation on the gospel texts as he edited his harmony. They, do not, however, agree about the nature of this influence or its cause. In addition, while Ishodad complains that Tatian did not write on the divinity of Christ, Eusebius included him in a list of apologists in whose works 'Christ is treated as God' (Eus, HE. V.28.4).

It is clear that the most these writers can do is alert us to a suspicion shared by many early writers. It is possible that some of them knew works of Tatian to which we have no access. It is equally, if not much more, possible that they had

13Jerome, Gal. 6:8 (quoted in Whittaker, Tatian, 82f). There may, however, have been some corruption of this text (see p83, note a).

${ }^{14}$ Theodoret, Haer. I.20. He reports that he found 200 churches in his diocese using the Diatessaron 'without recognising the craftiness of its composition'. These he removed, replacing them with Four Gospels.

15E. Ranke, Codex Fuldensis. Novum Testamentum Latine Interprete Hieronymo ex manuscripto Victoris Capuani (Marburg \& Leipzig, 1867) 2; translation from G. Quispel, Tatian and the Gospel of Thomas (Leiden, 1975) 20 (my emphasis).

16J.R. Harris, Fragments of the Commentary of Ephrem Syrus upon the Diatessaron (London, 1895) 14 (my emphasis). 
little direct knowledge of his work. In particular it is not clear that Eusebius had seen the Diatessaron, and Epiphanius clearly confused it with a Hebrew Gospel (see Panarion 46.1).

\section{The Diatessaron: Sources and Procedure}

'Tatian composed in some way a combination and collection of the gospels, and gave this the name of The Diatessaron (Tò Siò $\tau \varepsilon \sigma \sigma o ́(p \omega v)$ and this is still extant in some places' (Eus, HE. IV.29.6).

Unfortunately, Eusebius' statement is no longer true, and Tatian's Diatessaron must be reconstructed from later translations and commentaries.17 Among the many possibilities, there are three main sources which will be used in this study: 18

1. Ephraem's Commentary: This commentary, based on the Diatessaron, was written by St Ephraem Syrus (d. AD 373). It survives in a Syriac manuscript, (which preserves about three quarters of the commentary), ${ }^{19}$ an Armenian version, ${ }^{20}$ and

${ }^{17}$ It is impossible to be certain of the original language in which Tatian composed the Diatessaron. While scholars of a previous generation (e.g. Harnack, von Soden, Jülicher, Preuschen, Vogels and Kraeling) supported the idea of a Greek original; recent discussions (by, e.g., Plooij, Baumstark, Vööbus, Peters, Kahle and Higgins) have pointed towards a Syriac original. The most recent discussion is that by W.L. Petersen, New Evidence for the Question of the Original Language of the Diatessaron' Studien zum Text und zur Ethik des Neuen Testaments (FS H. Greeven; ed. W. Schrage; Berlin, 1986) 325-343.

${ }_{18}^{18}$ For general discussions of all the possible witnesses see B.M. Metzger, The Early Versions of the New Testament (Oxford, 1977) 10-25; A.J.B. Higgins, 'Luke 1-2 in Tatian's Diatessaron' JBL 103 (1984) 193-222; W.L. Petersen, The Diatessaron and Ephrem Syrus as Sources of Romanos the Melodist (CSCO 475; Lovain, 1985) 26-39.

${ }^{19}$ L. Leloir, Saint Éphrem Commentaire de l'Évangile concordant texte syriaque (manuscrit Chester Beatty 709) (CBM 8; Dublin, 1963). One additional folio was published by P. Ortiz Valdivieso, 'Un nuevo fragmento siríaco del Commentario de sa Efrén al Diatésaron (PPalau Rib. 2)' Stud. Pap. 5 (1966) 7-17; and 41 folios were acquired by the Chester Beatty Library in 1984 \& 1986, see L. Leloir, 'Le commentaire d'Éphrem sur le Diatessaron. Quarante et un folios retrouvés' $R B 94$ (1987) 481-518; and K.J. Cathcart, The Biblical and Other Early Christian Manuscripts of the Chester Beatty Library' Back to the Sources (FS D. Ryan; ed. K.J. Cathcart \& J.F. Healey; Dublin, 1989) 137ff. Cathcart estimates that less than 30 leaves remain undiscovered. 
Syriac fragments preserved in later commentators. 21 That Ephraem used Tatian's Diatessaron as his source is asserted by Dionysius Bar-Salibi (bishop of Amida, Mesopotamia, d. 1207) who was then quoting from a comment made by Isho'dad in AD 850.22 This conclusion is supported by the fact that his commentary begins with John 1.1, has no allusion to the genealogies, and continually alternates between gospels.

2. Arabic Translation: Two manuscripts of an Arabic translation of the Diatessaron exist (the Borgian and Vatican MSS).23 This translation is (in super-and sub-scriptions to the Borgian MS) said to be a translation made by Abu'l Faraj Abdulla ibn-at-Tayyib (d.1043) from a Syriac version of Tatian's Diatessaron into Arabic. ${ }^{24}$ The Syriac exemplar on which he depended was written by Isa ibn Ali al Motatabbib (d. 873) who was a pupil of Honain ibn Ishak. ${ }^{25}$ In other words we are at least one translation (maybe two) away from the original Diatessaron, and several copyings.

3. The Latin codex Fuldensis: This manuscript, copied between AD 541 and 546, preserves the Diatessaronic order. 26

${ }^{20}$ Two manuscripts (both dated 1195): L. Leloir, Saint Éphrem Commentaire de l'Évangile concordant, version arménienne (Louvain; Text: CSCO 137; Scriptores Armeniaci. i; 1953; Latin Translation: CSCO 145; Scriptores Armeniaci. ii; 1954).

${ }^{21}$ See Harris, Fragments; T. Baarda, 'A Syriac Fragment of Mar Ephraem's Commentary on the Diatessaron' NTS 8 (1961f) 287-300; L. Leloir, L'Évangile d'Éphrem d'après les oeuvres édités: Recueil des textes (CSCO 180, Subsidia 12; Louvain, 1958).

${ }^{22}$ Harris, Fragments, 14f; J.H. Hill, A Dissertation on the Gospel Commentary of S. Ephraem the Syrian (Edinburgh, 1896) 6, 9 f.

23P.A. Ciasca, Tatiani Evangeliorum Harmoniae Arabice (Rome, 1888); we have used A.-S. Marmadji, Diatessaron de Tatien (Beyrouth, 1935), which gives the Arabic text and French translation. We have generally cited the English translation from H.W. Hogg, 'The Diatessaron of Tatian' ANCL: Additional Volume (ed A. Menzies; Edinburgh, 1897) 33-138. For further information see A.J.B. Higgins, "The Arabic Version of Tatian's Diatessaron' JTS 45 (1944) 187-199.

${ }^{24} \mathrm{~T}$. Baarda, 'The Author of the Arabic Diatessaron,' in Early Transmission of Words of Jesus (Amsterdam, 1983) 207-249.

25Hogg, 'Dissertation', 130.

${ }^{26}$ The text has been assimilated to the Vulgate. Ranke, Fuldensis (for the text); see also Quispel, Tatian, 19-25; H.J. Vogels, Beiträge zur 
All of these show a clear and explicit connection with Tatian's Diatessaron. Later medieval gospel harmonies, such as the Dutch, Persian, Old High German, Flemish and Middle English harmonies, occasionally exhibit 'Tatianic readings', but as a whole are not dependent upon Tatian's work.27

Since they do not share exactly the same order of pericopes, do not have the same wording within the pericopes, and do not manifest the same text type, and have no readings that can be said with certainty to have originated with Tatian; there is no important sense in which they can be regarded as manifestations of the work of Tatian. 28

The Dutch harmony (Liège) explicitly says in the introduction that it is a new rendering of the Latin text of four Gospels into Dutch. ${ }^{29}$ The Persian harmony has an entirely different structure and layout from that of Tatian: it claims a Syriac original, 30 but the order of material is completely different from the order we know from Ephraem, the Arabic,

Geschichte des Diatessaron im Abendland (NTAbh VIII:1; Münster, 1919) 1-33.

27On the later history of various harmonies see J.N. Birdsall, "The Sources of the Pepysian Harmony and its Links with the Diatessaron' NTS 22 (1976) 215-223 (on Pepysian Harmonies); C. Peters, Das Diatessaron Tatians (OCA 123; Rome, 1939) (on German Harmonies); Vogels, Beiträge; Quispel, Tatian, J. fon Weringha, Heliand and Diatessaron (SG V; Assen, Netherlands, 1965).

28O.C. Edwards, 'Diatessaron or Diatessara?' Studia Patristica XVI (ed E. A. Livingstone; TU 129; Berlin, 1985) 92.

${ }^{29}$ D. Plooij (ed.), The Liège Diatessaron, edited with a Textual Apparatus (with C.A. Phillips \& A.H.A. Bakker; ET of Dutch text by A.J. Barnouw; Parts I-VIII; ALNR 29 \& 31; Amsterdam, 1929-1970). The Dutch text itself claims to be composed from Latin versions of the four gospels into a continuous life of Christ (p1f). This is disputed by Plooij, A Primitive Text of the Diatessaron (Leiden, 1923), who was supported by F.C. Burkitt, 'Tatian's Diatessaron and the Dutch Harmonies' JTS 25 (1924) 113-130.

30G. Messina, Diatessaron Persiano (BO 14; Rome, 1951). The manuscript (Laurentian MS XVII) was copied in 1547 by Ibrahim ben Shamas, from an original from the thirteenth century; which was translated from a Syriac base; see B.M. Metzger, 'Tatian's Diatessaron and a Persian Harmony of the Gospels' JBL 69 (1950) 261-280; A.J.B. Higgins, 'The Persian Gospel Harmony as a Witness to Tatian's Diatessaron,' JTS 3 (1952) 83-87. 
and Codex Fuldensis.31 This investigation will concentrate on the evidence supplied by Ephraem's commentary, and the Arabic translation (following the order and numbering of the Arabic). The Dutch and Persian Harmonies will be cited for support on matters of wording, as they generally have the greatest frequency of 'Tatianic readings'.32

\section{The Diatessaron and Tatian's Gospel Redaction}

\section{Introduction}

The task facing Tatian was not simple. To begin with four separate gospels and produce one connected, flowing narrative was difficult. Even more difficult was to include almost everything distinctive in each of the four gospels. Such care as must have been exercised in producing the text encourages us to seek for the writer's own touch on the narrative.

Such touches have often been noted in the area of Tatian's attitude towards marriage and in particular to the parents of Jesus. ${ }^{33}$ So, for example, the following changes were made:

Matt 1:19: 'her husband Joseph, being a just man. .'

Diatessaron: 'Joseph, because he was a just man. . .'34

Luke 2:33: 'his father and his mother'

Diatessaron: 'Joseph and his mother' 35

Luke 2:41, 43: 'his parents'

Diatessaron: 'his kinsfolk'. .'Joseph and his mother'.36

By means of these changes Tatian obscures the relationship between Joseph and Mary. ${ }^{37}$ In another expression of his

31The Persian begins with Mk. 1:1, then Jn. 1:1-14, then Lk. 1:1-4. The overall structure is completely different, with the work divided into four sections, with a different number of paragraphs in each (I.1-71; II.161 ; III.1-60; IV.1-58).

32Metzger, Versions, 17f, 23.

${ }^{33} \mathrm{Cf}$., Metzger, Versions, $34 \mathrm{f}$ (and see the introduction to this article).

34Ephraem (Hill, Dissertation, 78); Persian I.4 (Messina, 17).

35Arabic Dia. 2.41; Persian I.6 (Messina, 23); Dutch: 'Joseph and Mary' (Liège, 29).

36Arabic Dia. 3.25, 27; Persian (I.13; Messina, 31) follows the Arabic exactly, the Dutch supplies 'Joseph and Mary' for the first, and simply 'they did not know of it' for the second (Liège, 35f).

37Tatian was not alone in altering some of these texts. See A. Globe, 'Some Doctrinal Variants in Matthew 1 and Luke 2, and the Authority of the Neutral Text' CBQ 42 (1980) 52-72. 
Encratism, Tatian omits the accusation against Jesus (Matt 11:19), that he was 'a glutton and a drunkard' (Arabic 25.42; Ephraem).

\section{The General Framework}

In any combination of the canonical Gospels, basic choices must be made about the arrangement of material. Tatian locates the synoptic gospels within the Johannine framework, beginning with John 1:1-5 (more on this in a moment), and ending with John 21:25. This strategy also is followed at the chronological and geographical level, with the Johannine scenes in Jerusalem determining the basic chronological outline.

In the initial stages Tatian takes blocks of material from Luke and Matthew and John, but from the baptism of Jesus onwards the arrangement of the material from the four source-Gospels is more intricate and involved, with single verses and phrases drawn from different gospels, and inserted in various places. The Sermon is on the plain (but contains the extended sections of Matt 5-7). The cleansing of the temple is located at the beginning of the passion narrative (as in the synoptic gospels) and this takes John 3 with it to the later position (Arabic 32); the rest of John, from ch 8 follows from there (John 7:53-8:11 is lacking).

Obviously the whole arrangement misses the purpose behind the individual accounts at times; an example of this is the report of the crucifixion (see Arabic 51 \& 52). We have the traditional seven words from the cross in the following order: 1) 'Verily I say unto thee, Today shalt thou be with me in Paradise' (Luke 23:43); 2) 'Woman, behold thy Son. . .Behold, thy mother' (John 19:27); 3) 'Yail, Yaili, why hast thou forsaken me?'; 4) 'I thirst' (John 19:28); 5) 'Everything is finished' (John 19:30); 6) 'My Father forgive them; for they do not know what they do' (Luke 23:34); 7) 'My Father, into thy hands I commend my spirit.' (Luke 23:46).

Then follows (Arabic 52.8-13) the tearing of the temple curtain from top to bottom, the earthquake, the opening of the tombs, whereupon the officer, seeing this, said: "This man was 
righteous; and truly he was the Son of God'.38 The multitudes then also smote their breasts.

Various phrases from the long ending of Mark are found in the resurrection account. The penultimate chapter is John 21. The closing chapter (Arabic 55) consists of a conglomeration of Matt 28:16-20; Mark 16:14-20; Luke 24:4953; closing off with the statement of John 21:25 ('there are many other things which Jesus did...').

\section{The Incarnational Perspective}

From a christological perspective it is notable that Tatian begins with John 1:1-5.39 This places the whole work in the clear theological framework provided by John's 'In the beginning was the Word.' It is the theological, rather than the historical and literarily-specific Luke 1:1-4 which introduces Tatian's gospel.40

The Johannine prologue serves as a kind of inclusio for the birth narratives in the Diatessaron. The order of the birth narratives is as follows: 41

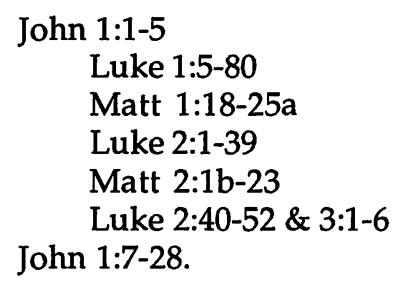

38The Persian here follows Mark only (IV.49; Messina, 358f), as does Ephraem: 'this was the Son of God'; see Hill, Diatessaron, 118; L. Leloir, Éphrem de Nisibe, Commentaire de l'Évangile concordant ou Diatessaron (SC 121; Paris, 1966) 363, cited as Leloir, Commentaire. ${ }^{39}$ So in the Arabic, Ephraem (Leloir, Syriaque, 2-7; Leloir, Commentaire, 43-46), and also in the list in Codex Fuldensis (Ranke, Fuldensis, 21) and the Liège (ch 1, p5). The Persian is an exception here, beginning at I.1 with Mk. 1:1: "The beginning of the Gospel of Jesus Christ, the son of God' before following with Jn. 1:1-14 then Lk. 1:1-4 (Messina, 4-7) (an indication of its independence from Tatian).

40Although Lk. 1:1-4 is found in the Persian, and in Fuldensis, it is not present in the other witnesses; it was presumably omitted by Tatian because it was thought to be specific to Luke.

41The ordering of the different versions is clearly tabulated in L. Leloir, 'Le Diatessaron de Tatian', Or. Syr. 1 (1956) 216-227; for a reconstructed order see I. Ortiz de Urbina, Vetus Evangelium Syrorum, et exinde excerptum Diatessaron Tatiani (BPM VI; Madrid: CSIC, 1967) XIIf. 
Thus Tatian's arrangement has the effect of explaining 'the Word became flesh' by means of the story of the virgin birth. This echoes exactly the way in which the relationship between these two christological moments was made in increasingly sophisticated ways by Christian writers in the second century. Early in the century Ignatius held the virgin birth and the incarnation of the Word in tension without relating them (Ignatius, Magn. 8.2 \& Eph. 7.2). Around AD 125 Aristides brought the virgin birth and the assumption of flesh into juxtaposition (Aristides, Apology, II). In the middle of the century Justin says: 'the Word, who is the first offspring of God, was born for us without sexual union, as Jesus Christ our Teacher. ..' (Apol. I.21). The second-century climax is reached

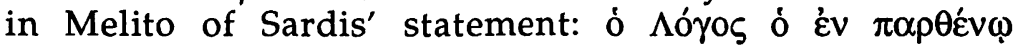

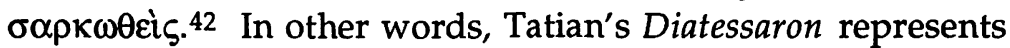
a narrative version of this theological harmonisation, which became an important theological principle in later debates. 43

\section{The Omission of the Genealogies}

Perhaps the most notable feature of Tatian's Diatessaron was the omission of the genealogies of Jesus (Matt 1:1-17; Luke 3:23-38). Although some witnesses do include genealogies (Fuldensis, Persian \& Dutch ${ }^{44}$ ); they are absent from the text of Ephraem, and from the Arabic translation, and this omission is mentioned by Theodoret and the ninth-century Bar-Ali.45 It seems clear that the absence of

${ }^{42}$ Quoted here from S.G. Hall, Melito of Sardis On Pascha and Fragments (OECT; Oxford, 1979) 85.

${ }^{43}$ Another form of this type of harmonisation between the incarnation of the Word and the virgin birth is found in the words of the angel in Protevangelium of James 11.2: 'Do not fear Mary, for you have found

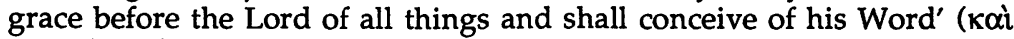

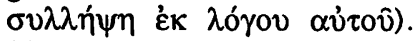

${ }^{44}$ The Persian gives the Lukan genealogy in I.11 (the corporal genealogy) and the Matthean in I.12 (as the spiritual genealogy) see Messina, 26-31. The Dutch includes the text of the Matthean genealogy (ch 8, Liège, 17-20), and comments that Luke also has a genealogy which progresses upward unlike Matthew's: 'but since many of them have been named by Saint Matthew, it is not necessary that they are renamed here' (Liège, 20). Plooij argued for the originality of the genealogies (Primitive, 17f).

${ }^{45}$ Theodoret's comment has already been quoted. Bar-Ali said: 'It [Tatian's Diatessaron] contains neither the natural nor the traditional 
the genealogies was noted and rectified by some later writers; for example, the (Arabic) Borgian MS adds them after the text of the Diatessaron. ${ }^{46}$ The addition of the genealogies would have redeemed the harmony for orthodox use.

Several of the 'orthodox' Fathers noted Tatian's omission of the genealogies (especially since with the exception of Luke 1:1-4 he otherwise omits nothing of such substance). Other groups or individuals in the Patristic period also omitted the genealogies of Jesus from their gospels. For example the Gospel of the Ebionites (according to Epiphanius Panarion, 30.14.2f) omitted Matthew's genealogy in order to facilitate their adoptionist reading of the gospel. Marcion was severely criticised by Irenaeus for omitting the Lukan genealogy (along with all the birth narrative): 'he mutilates the Gospel which is according to Luke, removing all that is written respecting the generation of the Lord'.47 This supports the view that the genealogies were regarded as supporting the humanity of Jesus. 48 Tatian's omission, therefore, could be indicative (if further supporting evidence is found) of a definite christological tendency. On this point it is also worth noting the way in which Tatian refrains from speaking of Jesus' physical parents.

Nevertheless, it is difficult to believe that Tatian intended to produce a form of the gospels which denied the humanity of Jesus. There are simply too many incidents from the life of Christ which he includes (some of which will be mentioned below). Although the omissions of the genealogies undoubtedly raised suspicions in many minds, it is possible that these omissions should be seen as a subset of Tatian's Encratism (avoiding mention of Jesus' married ancestors) rather than as indicators of christological heresy. 49

genealogy of our Lord Christ; and he who made it has on that account been anathematised' (from Harris, Diatessaron, 13f).

46Marmadji, 532-535.

47Irenaeus, Adv. Haer. I.27.2. Later Irenaeus emphasises that the genealogy safeguards the humanity of Jesus (Adv. Haer. III.22.2f).

48Cf., Jerome: Matthew 'opens his Gospel with the human genealogy of Christ' (Comm. Matt. prol.); and Augustine: Matthew emphasises Christ's birth according to the flesh (De Consensu 11.1).

${ }^{49}$ An alternative view might be that these alterations (including those concerning Jesus' parents) served to highlight the virgin birth by avoiding the identification of Jesus' father. 


\section{Some Uncertain Passages}

If we survey the Diatessaron for indications of possible christological influences on the redactional process we are faced with a complex situation.50 There are several places where some versions of the Diatessaron offer interesting christological readings, but uncertainty concerning either the original text or Tatian's reading makes it difficult to decide exactly who has changed what.

One example of this complex situation is the text which parallels John 1:18 (the original of which is uncertain):

Ephraem (I.2): 'only-begotten'51

Arabic (4.1): 'only-begotten God'52

Dutch (ch 21) \& Persian (I.17): 'only begotten Son'53

A further example is the text which parallels John 3:33 (which ends 'that God is true'):

Vatican Arabic (6.16): 'that he is truly God'

Borgian Arabic (6.16): 'that God is true'54

Persian (I.20): 'that God is true'55

In these passages, it is impossible to know whether Tatian has introduced an important christological variant or not. In addition, the Arabic translation often has variants which are not otherwise attested.56

50Hill, Diatessaron, 292-317 has a very useful list of the passages in which the Arabic version differs from the canonical gospels, we have culled variants from this list and compared the other versions.

${ }^{51}$ Leloir, Commentaire, 43: 'le Fils unique'; Leloir, Syriaque, 3: 'unigenitus', so also in Leloir, Arménienne, II, 2; Hill, Dissertation, 80. 52Marmadji, 30f.

53Liège, 41; Messina, 36f. SyrC supports 'only-begotten Son' at Jn. 1:18; the Peshitta supports 'only-begotten God'.

${ }^{54}$ Marmadji, 52; see also Hogg, Diatessaron', 52 n13.

55Messina, 42f. The text is not discussed in Ephraem and the Dutch supports neither reading (cf. Liège, 60).

56For example, the spiritualising of Lk. 4 at Dia. 5.37; the reference to 'my word' (rather than 'the word' or 'God's word' in the parable of the sower) at Dia. 16.48; the alterations made to the transfiguration at Dia. 24.3 ('made into the form of another person'); additional reports of Jesus knowing thoughts (Dia. 26.3 added to Lk. 15:3; Dia. 29.13 added to Lk. 16:14f). In these cases Ephraem, Dutch and Persian support a version closer to the Gospels. 
6. Some Specific Passages

There are many passages, supported by more than one witness to Tatian's Diatessaron, where christological alterations or interesting choices may be discerned.

Arabic Dia. 6.9 reads: 'many come to him' (par. John 3:26: 'all men come to him'). 57 This alteration (from 'all' to 'many') is interesting when compared with the clear scribal tendency to heighten the significance of Jesus by using 'all' in place of 'many' in several manuscripts. 58

In Arabic Dia. 17.36-53 we find an expansion of the rejection at Nazareth. Tatian (v. 39) adds: 'And many envied him, and did not apply their mind to him.' In v. 42 we read: 'they were suspicious of him', and that Jesus knew their thoughts. In v. 48 we read the following (Markan) version: 'he could not do many mighty works there, because of their unbelief, save that he laid his hands upon a few sick folk, and healed them.' 59 It is interesting to note that Tatian appears to follow the (more difficult) Markan version of the rejection.

At Arabic Dia. 21.3 we find a reference to Jesus spitting on his fingers added to the Markan report of the healing of the deaf and dumb man (Mark 7:33).60 Although only attested in the Arabic, the addition shows that in this case physical details were added to the account of Jesus' miracles.

Arabic Dia. 28.42-51 follows the Markan framework for the narrative concerning the rich young ruler: 'Good teacher, what is it that I must do that I may have eternal life?' Jesus said unto him, Why callest thou me good, while there is none good but the one, even God?'61 It is noteworthy that in a

57Marmadji, 51, not mentioned by Ephraem, but supported by Persian 1.20 (Messina, 43).

58Evidence from readings at Mt. 4:24; 7:28; 8:18; 9:35; 15:30; Mk. 1:34; Lk. 4:32, 36; 5:17 are discussed in P.M. Head 'Christology and Textual Transmission' NovT (forthcoming).

${ }^{59}$ So Arabic, only the proverbs are quoted in Ephraem. The Dutch (ch98) gives a different version: 'because of the unbelief of the people he did not perform there many miraculous works; and few sick ones did he heal there, because of their unbelief' (Liège, 184f). The Persian (III.2) also follows Mk. 6:5 (Messina, 192f).

60Marmadji, 200f. Not attested in Ephraem or Dutch. The Persian (II.15) follows Mark.

61Marmadji, 272f (ET from Hogg, 'Diatessaron', 87); and also Ephraem XV.1f (Leloir, Commentaire, 263f: in Syriac and Armenian); and the 
clear choice between the versions Tatian follows Mark rather than Matthew (perhaps because it is also supported by Luke); as he also apparently did at the rejection at Nazareth.

According to Arabic Dia. 41.1 Jesus says: 'Therefore, behold, I, the wisdom of God, am sending unto you the prophets, and apostles, and wise men, and scribes. . '62 This redaction of the two forms of the saying (Matt 23:34 // Luke 11:49) makes explicit the identification of Jesus as Wisdom (which seems to be only implicit in Matthew's redaction).

The scene in the garden includes reference to the disputed verses of Luke 22:43f, but even more interesting is the addition: 'being afraid he prayed continuously; and his sweat became like a stream of blood' (Arabic Dia. 48.16f63). The addition of a reference to Jesus' emotions is noteworthy, and a corrective to the view that the emotions of Jesus were an embarrassment to the early Christians.

The reports of the passion and resurrection are generally very close to the Gospel reports (although the harmonising factor provides for an interpretive narrative, and obscures the individual emphases of the evangelists). There are, however, no christologically important variants that we noticed. 64

\section{7. 'Jesus' in the Diatessaron}

A notable general tendency throughout the Diatessaron is the substitution of 'Jesus' for Luke's references to 'the Lord' in the narrative settings. Examples of this are as follows:

Persian (II.39; Messina, 154f). Only the Dutch follows Matthew (ch 145, Liège, 345).

62Not attested in Ephraem, nor in Persian. The Dutch harmonises differently: "Therefore the wisdom of God spoke formerly: "I shall send to you my prophets. . ."' (ch 192, Liège, 584).

63Marmadji, 459; Hogg, 'Diatessaron', 117. This is supported by the Persian (IV.36; Messina, 334f: 'E quando prego in timore. . .'). Ephraem (XX.11) attests the second half of this (following Luke): 'his sweat became as it were drops of blood' (Leloir, Commentaire, 350; Hill, Dissertation, 115). The Dutch has '... with the sadness in which he was he started praying longer. . his sweat became shaped like drops of blood running down to earth' (ch 233; Liège, 684f).

${ }^{64}$ The Arabic places some emphasis on Jesus' body (Dia. 52.28, 37), but is not supported by the other versions. 


\section{Luke}

7:13: 'when the Lord saw her. .'

7:19: 'sent them to the Lord...'

10:1a: 'the Lord appointed seventy'

10:41: 'the Lord answered her. ..'

11:39: 'the Lord said to him. ..'

12:42: 'And the Lord said. ..'

13:15: 'Then the Lord answered. ..'

19:8: 'and said to the Lord. ..'

22:61: 'And the Lord turned. ..'
Arabic Diatessaron 65

11.19 Jesus saw. ..66

13.39 'he sent them to Jesus' 67

15.15 Jesus appointed. . .68

13.34 'Jesus answered. . .'69

20.14 Jesus said. . . 70

43.2: 'Jesus said. . .'71

27.45 Jesus answered. ..'72

31.22 '. . said to Jesus 73

49.16 Jesus turned. . .74

This appears to be a genuine Tatianism.75 This is particularly interesting in light of the known tendency of the Old Syriac versions to add 'Lord' to the Gospel narratives. ${ }^{76}$ Little christological significance can be attached to these alterations, however, since the primary motivation is probably simply to maintain a consistent form of reference to Jesus throughout the narrative.

65None of the following are attested in Ephraem's commentary. But all are supported by the Arabic and at least one of the other versions.

66Dutch: 'Jesus' (Liège, 108); Persian: 'Jesus' (I.69, Messina, 90f).

67Dutch: 'Jesus' (Liège, 143); Persian: 'Jesus' (I.70, Messina, 90f).

68Dutch: 'Jesus' (Liège, 151); Persian: 'Jesus' (III.7, Messina, 202f).

69Dutch: 'Jesus' (Liège, 142); Persian: 'Jesus' (III.26, Messina, 226f).

70Dutch: 'Jesus' (Liège, 215); Persian: no intro (II.10, Messina, 112f).

71Dutch: not attested; Persian: 'Jesus' (I.63, Messina, 82f).

72Dutch: 'Jesus' (Liège, 329); Persian: 'Jesus' (II.22, Messina, 128f).

73Dutch: 'Jesus' (Liegge, 398); Persian: 'Jesus' (III.32, Messina, 232f).

74Dutch: 'Jesus' (Liège, 701); Persian: 'Jesus' (IV.40, Messina, 342f).

75Cf., also Arabic Dia. 45.17: 'Jesus. . . [said to him]'; Persian: 'Jesus' (IV. 26, Messina, 316f). Dutch: 'Jesus' (Liège, 635). This parallels Lk. 22:31 where the Majority text reads 'Lord', while NA26 has nothing, (with P75 \& B in particular). There are possible exceptions to this rule in single witnesses. For example Arabic Dia. 13.32 has 'Lord' (as does Lk. 10:39, the source: 'the Lord's feet'); but the other witnesses are mixed: Ephraem: 'Jesus' (VIII.15); Dutch: 'his feet' (Liège, 142); Persian: 'piedi del Signore' (III.26, Messina, 226f). In two places (not attested in Ephraem, Persian or Dutch) the Arabic Dia. has 'Lord' (Dia. 33.9 // Lk. 17:5; Dia. 42.50 / / Lk. 17:37).

76See F.C. Burkitt, Evangelion Da-Mepharreshe (Cambridge, 1904)II.97. 


\section{Conclusion}

In his production of the Diatessaron Tatian pursued a relatively conservative procedure: including practically everything from each Gospel. At a conceptual level, his redaction served to integrate the christological presentations of the individual Gospels, particularly the connection between Luke's 'conception by the Spirit', and John's 'incarnation of the Word'. In this Tatian clearly displays his second theological century milieu very clearly. Other indications of his interest to make certain passages more explicitly christological can be found: Jesus' knowledge of thoughts; more explicit versions of the transfiguration and the wisdom saying; and the overall structuring of the introduction around the Johannine prologue. This process of making more explicit christological presentations is common in the second century (and later!).

While the omission of the genealogies (especially when combined with the reluctance concerning Jesus' parents) does (with Theodoret) serve to obscure Jesus' connection with the Davidic line, there is little other evidence of a rejection of the humanity of Jesus. Indeed, in some ways Tatian goes out of his way to highlight the humanity of Jesus: the use of 'Jesus' throughout; Jesus' fear in Gethsemane; the inclusion of the Markan versions: 'Why do you call me good?' (Mark 10:18) and 'he could not do many mighty works there' (Mark 6:5); the mention of Jesus spitting on his fingers; and one example of altering 'all men' to 'many'. Thus Tatian was able not only to integrate separate theologies of the four gospels, but to do it without sacrificing the real humanity of Jesus (unlike so many others in the early church). For this reason it is perhaps most likely that the omission of the genealogies should be regarded as a subset of Tatian's encratitic alterations

In conclusion it must be said that Tatian's fingerprints have not left clear traces. There are some indications that he filtered the gospel texts through his own christological grid (like all Christians, including biblical scholars!), but his alterations were not great, and this explains the value the work was seen to have even among orthodox groups. That Tatian's redaction reflects his own second century interests cannot be denied, but evidence is certainly lacking that he carried out any consistent, thorough and vigorous reinterpretation of the Gospel texts. 